\title{
Glycolipid antigen induces long-term natural killer T cell anergy in mice
}

\author{
Vrajesh V. Parekh, ${ }^{1}$ Michael T. Wilson, ${ }^{1}$ Danyvid Olivares-Villagómez, ${ }^{1}$ Avneesh K. Singh, ${ }^{1}$ Lan Wu, ${ }^{1}$ \\ Chyung-Ru Wang, ${ }^{2}$ Sebastian Joyce, ${ }^{1}$ and Luc Van Kaer ${ }^{1}$
}

1Department of Microbiology and Immunology, Vanderbilt University School of Medicine, Nashville, Tennessee, USA. 2Department of Pathology, University of Chicago, Chicago, Illinois, USA.

\begin{abstract}
Natural killer T (NKT) cells recognize glycolipid antigens presented by the MHC class I-related glycoprotein CD1d. The in vivo dynamics of the NKT cell population in response to glycolipid activation remain poorly understood. Here, we show that a single administration of the synthetic glycolipid $\alpha$-galactosylceramide $(\alpha-$-GalCer) induces long-term NKT cell unresponsiveness in mice. NKT cells failed to proliferate and produce IFN- $\gamma$ upon $\alpha$-GalCer restimulation but retained the capacity to produce IL-4. Consequently, we found that activation of anergic NKT cells with $\alpha$-GalCer exacerbated, rather than prevented, B16 metastasis formation, but that these cells retained their capacity to protect mice against experimental autoimmune encephalomyelitis. NKT cell anergy was induced in a thymus-independent manner and maintained in an NKT cell-autonomous manner. The anergic state could be broken by IL-2 and by stimuli that bypass proximal TCR signaling events. Collectively, the kinetics of initial NKT cell activation, expansion, and induction of anergy in response to $\alpha$-GalCer administration resemble the responses of conventional $T$ cells to strong stimuli such as superantigens. Our findings have important implications for the development of NKT cell-based vaccines and immunotherapies.
\end{abstract}

\section{Introduction}

Natural killer T (NKT) cells are a unique subset of T lymphocytes with surface receptors and functional properties shared with conventional T cells and NK cells (1-8). Prototypical NKT cells, often referred to as invariant NKT cells, have restricted TCR expression (V $\alpha 14-J \alpha 18 / V \beta 8.2$ in mice and V $\alpha 24-J \alpha 18 / V \beta 11$ in humans) and recognize glycolipid antigens such as the marine sponge-derived agent $\alpha$-galactosylceramide ( $\alpha$-GalCer) presented by the MHC class I-like protein CD1d. The most remarkable property of NKT cells is their capacity to rapidly produce large amounts of cytokines, including IFN- $\gamma$ and IL-4, in response to TCR engagement. In turn, activation of NKT cells in this manner sets off a cascade of events that leads to the activation of a variety of innate and adaptive immune cells. These immunomodulatory properties of NKT cells have been successfully exploited for prophylactic and therapeutic purposes, as exemplified by the capacity of repeated $\alpha$-GalCer injections to prevent tumor metastases (9) and to protect susceptible mice against autoimmune diseases such as type 1 diabetes (10-13) and experimental autoimmune encephalomyelitis (EAE) (14-16). However, $\alpha$-GalCer treatment also has a number of unwanted side effects in mice, such as the induction of liver toxicity (17), abortions (18), and exacerbation of atherogenesis (19). Therefore, a thorough understanding of NKT cell responses to antigenic stimulation will be required to develop effective and safe NKT cell-based therapeutics.

One hallmark of the adaptive immune response is its capacity to induce long-term memory in response to specific peptide antigens. In the case of NKT cells, however, the secondary immune response to $\alpha$-GalCer, as compared with the primary response to this antigen, is typically blunted (20-22). However, the biological basis for this

Nonstandard abbreviations used: B6, C57BL/6; EAE, experimental autoimmune encephalomyelitis; $\alpha$-GalCer, $\alpha$-galactosylceramide; NKT, natural killer T (cell). Conflict of interest: The authors have declared that no conflict of interest exists.

Citation for this article: J. Clin. Invest. 115:2572-2583 (2005).

doi:10.1172/JCI24762. phenomenon remains unclear. Until recently, it was thought that, within 24 hours of $\alpha$-GalCer administration to mice, most peripheral NKT cells die by activation-induced cell death, followed by repopulation of these cells in peripheral organs several days later by means of recruitment from a pool of expanded NKT cells in the bone marrow (23-25). However, it is now clear that the rapid disappearance of NKT cells after $\alpha$-GalCer administration is due to downmodulation of NKT cell surface receptors such as the invariant TCR and NK1.1, which are used to identify these cells (26-28). Instead of dying, NKT cells rapidly proliferate in response to $\alpha$-GalCer, resulting in a significantly expanded NKT cell population 3 days after $\alpha$-GalCer administration $(26,27)$. Following this period of rapid expansion, most NKT cells die by homeostatic mechanisms, reaching steady-state levels around days $7-10$ after $\alpha$-GalCer injection $(26,27)$. As such, these $\alpha$-GalCer-activated NKT cells can exhibit their effector functions for an extended time period and may potentially participate in subsequent immune responses, perhaps in an altered manner.

Here we have investigated the response of NKT cells, activated in vivo with $\alpha$-GalCer, to restimulation with this antigen ex vivo or in vivo. We found that $\alpha$-GalCer administration to mice induces a state of unresponsiveness in NKT cells with respect to their capacity to proliferate, produce cytokines, transactivate other cell types, and prevent tumor metastasis. Peripheral NKT cell unresponsiveness induced by $\alpha$-GalCer resembled the tolerance that is induced in conventional T cells by strong stimuli such as superantigens. Because $\alpha-$ GalCer and related glycolipids have promising therapeutic activities, our findings have important implications for the development of effective and safe NKT cell-based vaccines and immunotherapies.

\section{Results}

Mice are unresponsive to $\alpha$-GalCer rechallenge in vivo. Prior studies have shown that the recall response of mice to $\alpha$-GalCer, as compared with the primary response, is typically suppressed (20-22). To determine the biological basis for this phenomenon, we first performed kinetic experiments to evaluate the in vitro NKT cell 
A
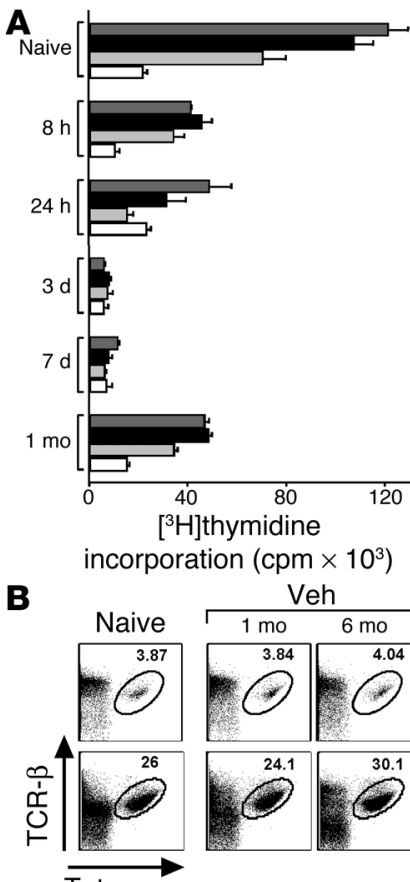

Veh
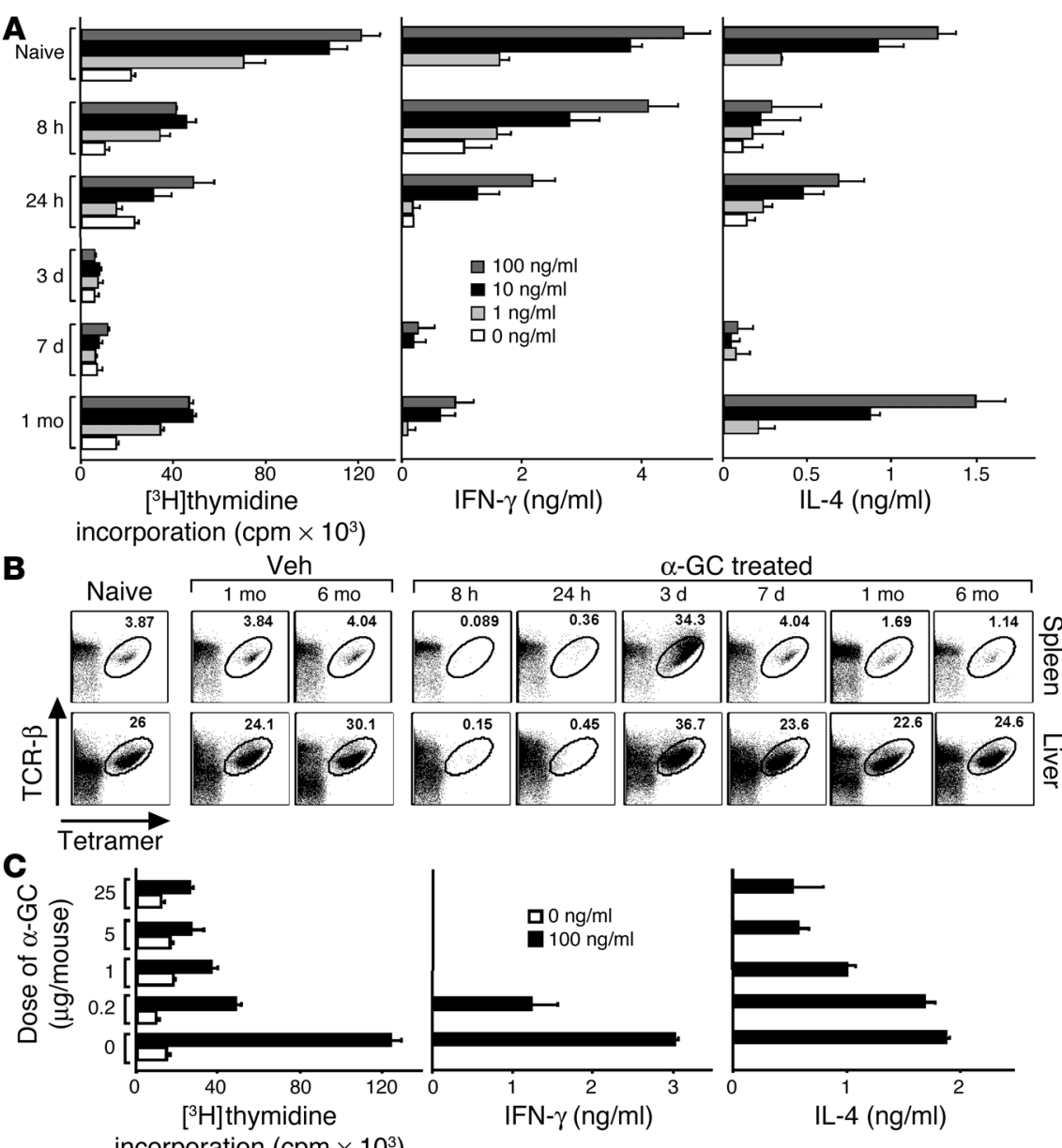

incorporation $\left(\mathrm{cpm} \times 10^{3}\right)$

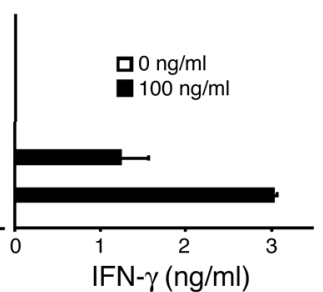

IFN- $\gamma(\mathrm{ng} / \mathrm{ml})$

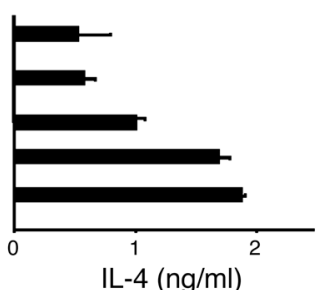

$\mathrm{IL}-4$ (ng/ml)

\section{Figure 1}

$\alpha$-GalCer induces unresponsiveness to rechallenge with this antigen in mice. (A) The in vitro recall response of mice to $\alpha$-GalCer immunization. Mice were injected with $5 \mu \mathrm{g}$ $\alpha$-GalCer (i.p.) and sacrificed at the indicated time points, and splenocytes $\left(2 \times 10^{5}\right.$ per well) were cultured with graded doses of $\alpha$-GalCer. After 3 days, proliferation was assessed by $\left[{ }^{3} \mathrm{H}\right]$ thymidine incorporation, and culture supernatants were evaluated for IL-4 and IFN- $\gamma$ levels by ELISA. Proliferation results represent the mean \pm SEM of triplicate wells, and cytokine results represent the mean \pm SEM of 2 mice. Representative data of 4 individual experiments are shown. (B) In vivo dynamics of the NKT cell population in response to $\alpha$-GalCer $(\alpha-G C)$ administration. Mice were injected with $\alpha$-GalCer or vehicle (veh), spleen or liver mononuclear cells were prepared at the indicated time points, and cells were stained with anti-TCR- $\beta-$ FITC, tetramer-PE, and anti-B220-peridinin chlorophyll protein (anti-B220-PerCP) and analyzed by flow cytometry. Numbers indicate the percentage of TCR $-\beta+$ tetramer ${ }^{+}$cells among B220- cells. A representative of 3 separate experiments is shown. (C) Influence of the injected $\alpha$-GalCer dose. Mice were treated with the indicated doses of $\alpha$-GalCer and analyzed 1 month later as in $\mathbf{A}$. recall response in mice injected with a single dose of $\alpha$-GalCer $(5 \mu \mathrm{g} /$ mouse, i.p.). Results showed that splenocytes from $\alpha-\mathrm{Gal}$ Cer-injected mice, as compared with naive splenocytes, quickly lost their capacity to proliferate and produce cytokines upon in vitro restimulation with $\alpha$-GalCer (Figure 1A). This blockade in proliferation and cytokine production was maximal at 3-7 days after the initial $\alpha$-GalCer injection and persisted for at least 1 month. Consistent with prior studies $(20,29)$, the blockade in proliferation and IFN- $\gamma$ production was more pronounced than that in IL-4 production. A characteristic feature of anergy in conventional $\mathrm{T}$ cells is the inability to produce IL-2 upon restimulation (30). In agreement with this concept, spleen cells failed to produce IL- 2 in response to $\alpha$-GalCer restimulation at 3 days, 7 days, and 1 month after $\alpha$-GalCer administration (data not shown).

To evaluate effects of $\alpha$-GalCer administration on the prevalence of NKT cells, we stained these cells in the spleen and liver at different time points after $\alpha$-GalCer injection. Consistent with prior studies $(23,31)$, we found that, rapidly (8-24 hours) after $\alpha$-GalCer administration, NKT cells became undetectable by tetramer staining, as a result of TCR downregulation (Figure 1B). NKT cells then expanded, reaching maximal levels at 3 days, and then slowly reduced in numbers. At the 1-month time point, percentages of NKT cells in the spleen were reduced approximately 2 -fold, as compared with those in vehicle-injected, age-matched mice. This trend in the decline of NKT cell numbers in the spleen continued until at least 6 months after $\alpha$-GalCer injection (Figure 1B). However, in the liver, NKT cell num- bers remained relatively stable and similar to those in vehicle-injected mice between 7 days and 6 months after $\alpha$-GalCer administration. These differences between liver and spleen may be due to alterations in trafficking of unstimulated versus $\alpha$-GalCer-activated NKT cells.

To determine whether the unresponsiveness to $\alpha$-GalCer was due to depletion of all peripheral NKT cells and emergence of anergic NKT cells from the thymus, as observed in protocols of chronic $\alpha$-GalCer administration (32), we performed experiments with thymectomized mice. The results were similar to those obtained in nonthymectomized animals (data not shown), providing strong evidence that the observed unresponsiveness to $\alpha$-GalCer is due to peripheral rather than central tolerance mechanisms. However, IL-4 production during the recall response of thymectomized mice, as compared with sham-thymectomized mice, was reduced (data not shown), suggesting that newly emigrated thymic NKT cells, which have an IL-4 cytokine production profile $(33,34)$, contribute to the residual IL-4 production that is seen in the recall response to $\alpha$-GalCer by euthymic animals (Figure 1A).

Next, we tested whether the blunted recall response to $\alpha$-GalCer stimulation was dependent on the dose of $\alpha$-GalCer used for injection. Results showed that $\alpha$-GalCer induced unresponsiveness over doses ranging from 0.2 to $25 \mu \mathrm{g}$, although a dose of $1 \mu \mathrm{g}$ or higher was most effective (Figure 1C).

$\alpha$-GalCer induces long-term NKT cell anergy in mice. Next, we determined the cellular basis for the observed resistance of mice to $\alpha$-GalCer restimulation. For this purpose, we compared the dynam- 


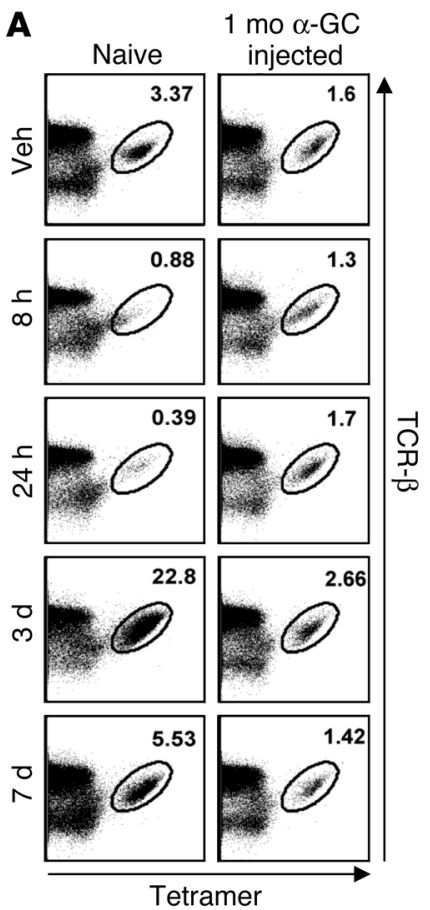

D
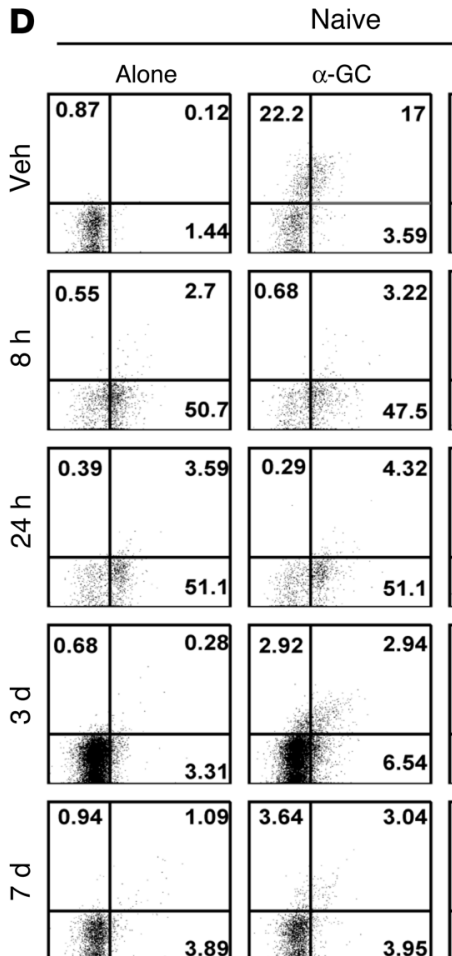

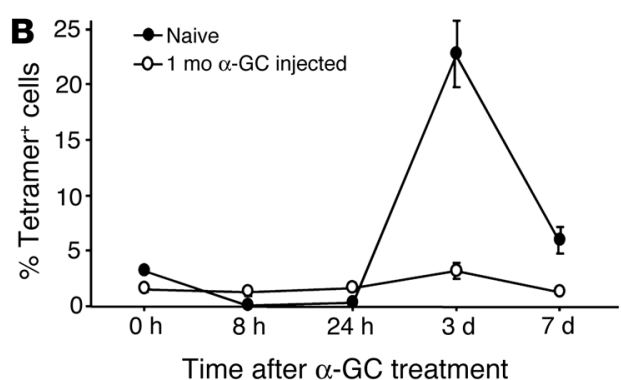

c

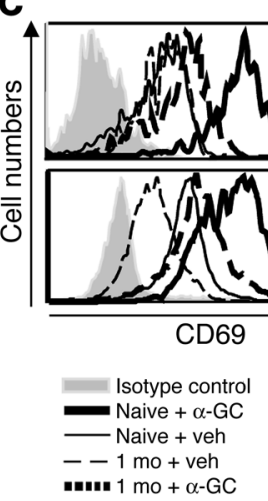

1 mo $\alpha-G C$ injected
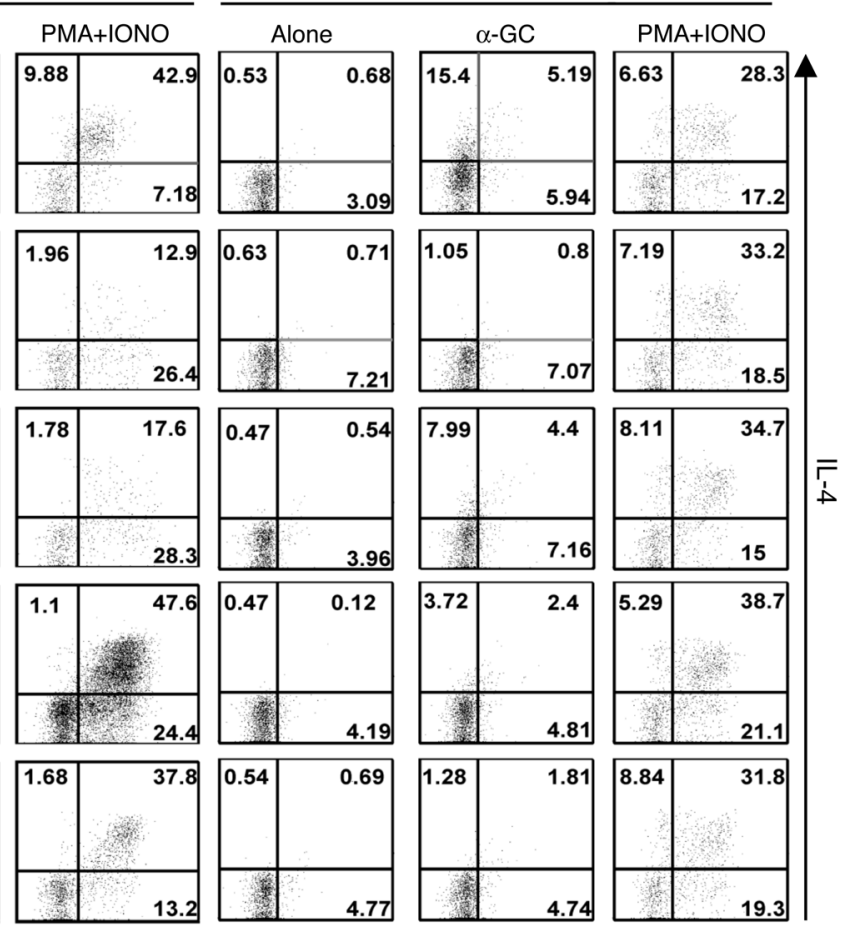

IFN- $\gamma$

ics of the NKT cell response to $\alpha$-GalCer administration in naive mice versus mice that had been injected 1 month earlier with a single dose of $\alpha$-GalCer. In naive mice, $\alpha$-GalCer administration resulted in the typical pattern of NKT cell "disappearance," expansion, and homeostatic contraction that we and others have described $(26,27)$ (Figure 2, A and B). In sharp contrast, NKT cells from mice injected 1 month earlier with $\alpha$-GalCer were significantly resistant to TCR downregulation and failed to expand in response to $\alpha$-GalCer rechallenge, indicating a blockade in TCR-mediated activation and proliferation. Consistent with these findings, NKT cells from spleen and liver failed to substantially enhance CD69 and CD40 ligand (CD40L) expression upon $\alpha$-GalCer restimulation (Figure 2C).

To determine whether the observed blockade in NKT cell proliferation was accompanied by altered cytokine production, we compared the intracellular IL- 4 and IFN- $\gamma$ profile of NKT cells from naive and $\alpha$-GalCer-pretreated mice following $\alpha$-GalCer injection. 

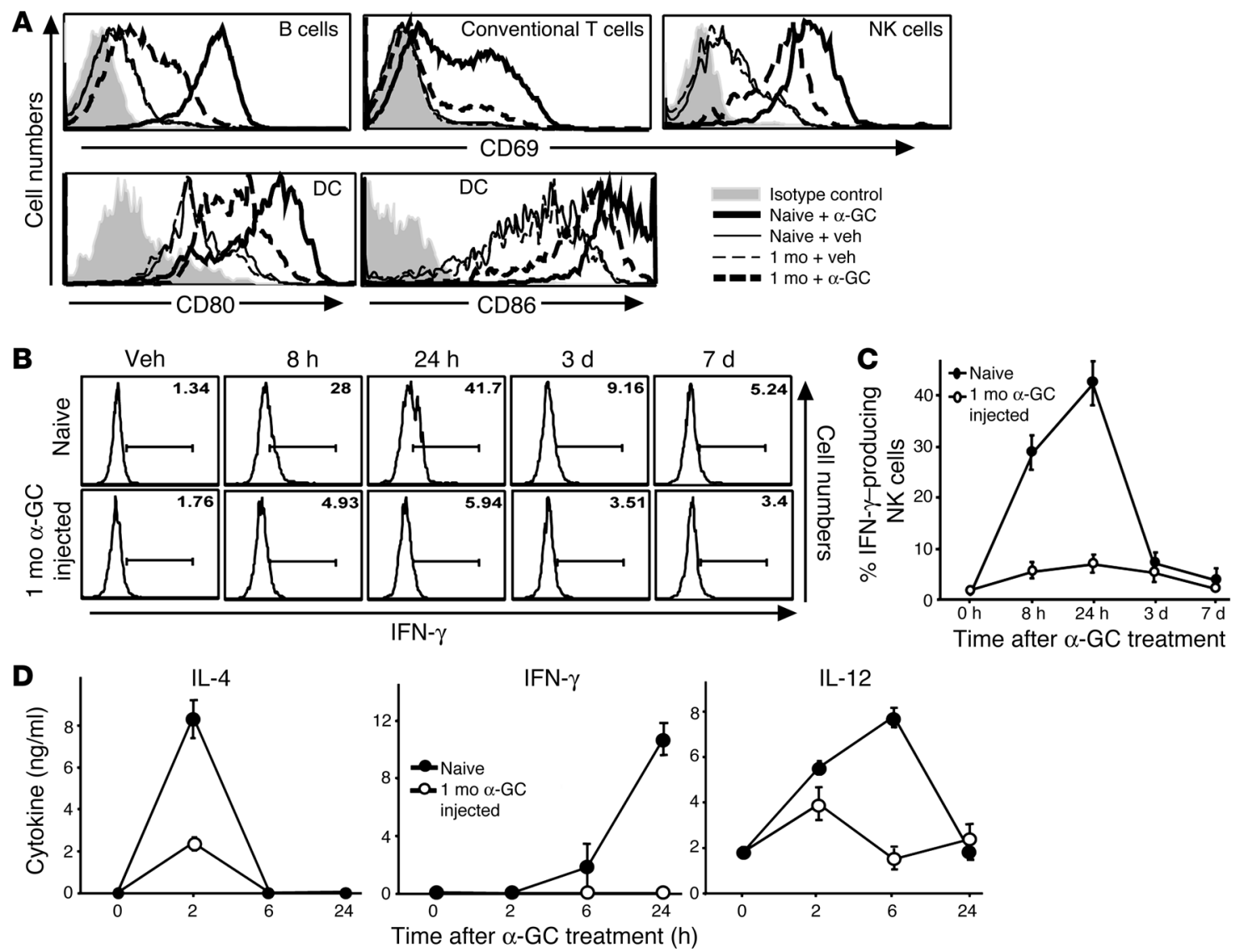

Figure 3

Anergic NKT cells are defective in transactivating B cells, conventional T cells, NK cells, and DCs. Naive mice or mice injected with $\alpha$-GalCer $(5$ $\mu \mathrm{g} /$ mouse, i.p.) 1 month earlier were reinjected with $\alpha$-GalCer or vehicle. (A) Expression of activation markers. Splenocytes were prepared after 24 hours and stained with different combinations of tetramer-PE, anti-B220-PerCP, anti-TCR- $\beta$-allophycocyanin, anti-NK1.1-PE, and/or antiCD69-FITC. CD69 expression was evaluated on NK cells (B220-TCR- $\left.\beta-N K 1.1^{\text {high }}\right)$, B cells (B220+TCR- $\left.\beta^{-}\right)$, and conventional T cells (B220-TCR- $\beta^{+}$ tetramer-). Alternatively, cells were stained with anti-CD11C-allophycocyanin, anti-CD80-FITC, and anti-CD86-PE. Expression of CD80 and CD86 was evaluated on CD11 chigh DCs. (B) IFN- $\gamma$ production by NK cells. Splenocytes were prepared at the indicated time points, cultured with GolgiPlug for 6 hours, and stained with anti-CD3-PerCP and anti-NK1.1-PE followed by anti-IFN- $\gamma-$ FITC or isotype-control Ab. Intracellular IFN- $\gamma$ expression by NK1.1 ${ }^{\text {high }} \mathrm{CD}^{-}$cells was evaluated. Specificity of staining was demonstrated with isotype controls (Supplemental Figure 1). (C) Graphical representation of the data from B. (D) Serum cytokine levels. Naive mice or mice injected 1 month earlier with $\alpha$-GalCer were injected with $\alpha$-GalCer or vehicle. Mice were bled at the indicated time points, and serum IL-4, IFN- $\gamma$, and IL-12 levels were measured by ELISA. Data shown represent the mean \pm SEM of 4 mice per group. Representative data of 3 individual experiments are shown.

At different time points after $\alpha$-GalCer readministration, splenocytes were cultured in vitro with plain medium, $\alpha$-GalCer, or PMA plus ionomycin for 6 hours before intracellular detection of cytokines. Consistent with prior results $(20,21,35)$, NKT cells from naive mice secreted both IL- 4 and IFN- $\gamma$ in response to $\alpha$-GalCer injection, with a gradual decrease in the strength of the response, and a switch from predominant IL- 4 to predominant IFN- $\gamma$ production (Figure 2D). In sharp contrast, in $\alpha$-GalCer-pretreated animals, cytokine production was profoundly suppressed at all time points. However, while IFN- $\gamma$ production was strongly blunted, IL-4 production was only partially suppressed. Importantly, culture with PMA plus ionomycin, which bypasses proximal steps in TCR signaling, was able to break this blockade in cytokine production.

We conclude that a single injection of $\alpha$-GalCer induces longterm hyporesponsiveness of NKT cells in mice and that this anergic phenotype can be broken by stimuli that bypass proximal TCR signaling events.
Anergic NKT cells are impaired in their capacity to transactivate other cells. Prior studies have shown that in vivo activation of NKT cells with $\alpha$-GalCer results in the transactivation of a variety of cells, including DCs, NK cells, B cells, and conventional T cells (4-7). Therefore, we tested the capacity of NKT cells from mice injected 1 month earlier with $\alpha$-GalCer, upon reinjection of $\alpha$-GalCer, to induce CD69 expression on T, B, and NK cells, and CD80 and CD86 expression on DCs. Results demonstrated a substantial defect in transactivation of each of these cell types (Figure 3A).

Many of the in vivo immunomodulatory activities of $\alpha$-GalCer are mediated by the capacity of activated NKT cells to induce IFN- $\gamma$ production by NK cells $(24,36)$. Therefore, we tested anergic NKT cells for this property of NKT cell function. Results showed that anergic NKT cells are unable to induce significant IFN- $\gamma$ production by NK cells (Figure 3, B and C), which is consistent with prior studies (22).

One hallmark of the immune response of NKT cells to $\alpha$-GalCer is a rapid rise in serum cytokines, produced by NKT cells themselves 
A
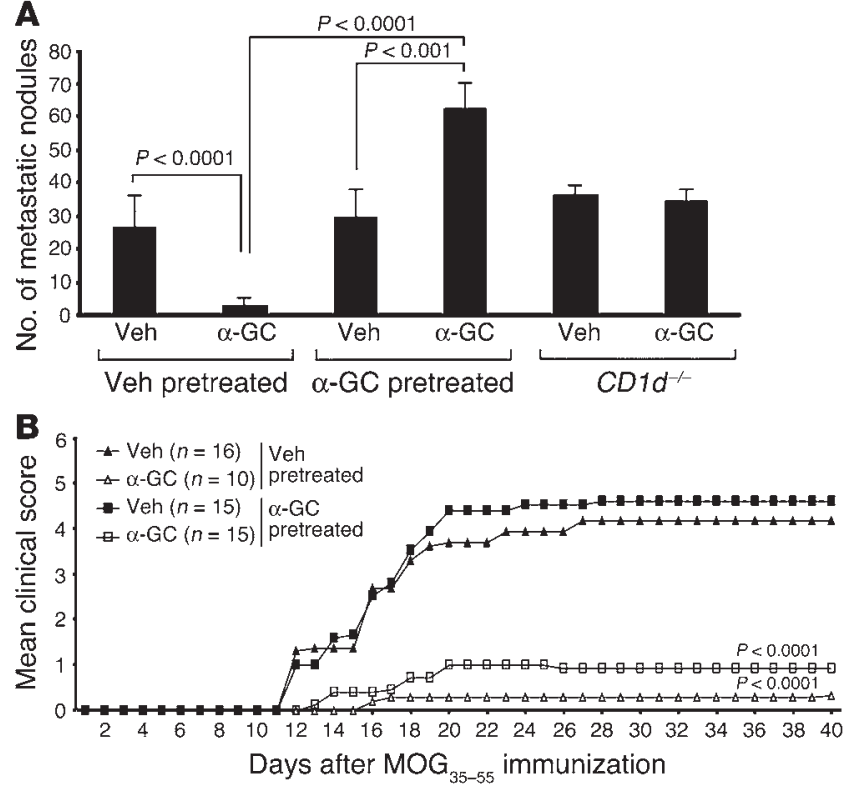

as well as by other cell types activated subsequently to NKT cell activation (4-7). We therefore tested the capacity of $\alpha$-GalCer to induce IL-4, IFN- $\gamma$, and IL-12 in the serum of mice injected 1 month earlier with $\alpha$-GalCer. Results showed a significantly blunted response for each of these cytokines (Figure 3D). However, consistent with our in vitro studies (Figure 1A) and intracellular cytokine data (Figure 2D), serum IL-4 levels were only partially reduced. Because IL-12 and IFN- $\gamma$, observed in the serum of $\alpha$-GalCer-injected mice, are largely produced by APCs and NK cells, respectively, these findings indicate that anergic NKT cells have profound defects in the $\alpha$-GalCer-induced transactivation of APCs and NK cells.

Anergic NKT cells are unable to prevent $B 16$ metastases but retain their capacity to prevent EAE. $\alpha$-GalCer has a number of potent immunomodulatory activities in mice, including the prevention of tumor metastases and Th1-dominant autoimmunity (37). Therefore, we tested the capacity of $\alpha$-GalCer-activated, anergic NKT cells to prevent B16 metastases and EAE. Mice were injected with $\alpha$-GalCer or vehicle, and, 1 month later, these animals were challenged with B16 tumor cells or $\mathrm{MOG}_{35-55}$ peptide plus adjuvant for induction of EAE. Mice were then treated with a series of $\alpha$-GalCer or vehicle injections, followed by evaluation of lung metastases and EAE disease. Results demonstrated that $\alpha$-GalCer was unable to prevent the development of lung metastases in $\alpha$-GalCer-pretreated mice (Figure 4A and Supplemental Figure 2; supplemental material available online with this article; doi:10.1172/JCI24762DS1). Instead, the number and size of tumor nodules in the lungs of these animals were increased. In sharp contrast, $\alpha$-GalCer retained its capacity to prevent EAE in $\alpha$-GalCer-pretreated mice (Figure $4 \mathrm{~B}$ and Supplemental Table 1).

$\alpha$-GalCer-induced NKT cell anergy is cell autonomous. Recent studies have suggested a role of regulatory $\mathrm{T}$ cells and tolerogenic DCs in the induction and maintenance of peripheral tolerance $(30,38)$. Therefore, we investigated whether the observed NKT cell anergy is cell autonomous. For this purpose, we cultured splenic DCs, purified from mice at different time points after $\alpha$-GalCer injection, with liver NKT cells purified from the same animals, in the presence of $\alpha$-GalCer. Results showed that NKT cells derived from

\section{Figure 4}

Anergic NKT cells are unable to protect mice against lung melanoma metastases but retain their capacity to prevent EAE. (A) Determination of B16 tumor lung metastasis formation. B6 mice were treated with $\alpha$-GalCer or vehicle, and, 1 month later, mice were challenged i.v. with $3 \times 10^{5}$ B16 melanoma cells and treated with $\alpha$-GalCer $(5 \mu \mathrm{g} /$ injection) or vehicle at 0,4 , and 8 days after the tumor challenge. Mice were sacrificed after 15 days, and the number of metastatic nodules was counted in the lungs. Results shown are the average of 2 experiments with 6 mice in each group per experiment and are representative of a total of 3 experiments with a total of at least 18 mice in each group. Representative photographs of lungs from these animals are shown in Supplemental Figure 2. (B) Modulation of EAE. B6 mice were treated with $\alpha$-GalCer or vehicle, and, 1 month later, EAE was induced. Mice were treated with $\alpha$-GalCer ( $5 \mu \mathrm{g} /$ injection) or vehicle on days 0,4 , and 7. Data shown represent the average values of 2 experiments with the number of mice indicated in each group. Data and statistical values are summarized in Supplemental Table 1.

naive mice proliferated and secreted cytokines at normal or slightly reduced levels in the presence of DCs derived from all mice (Figure 5A). Only the proliferative responses of naive NKT cells to DCs isolated at day 7 were significantly different from the responses of naive NKT cells to DCs isolated at day 0 after $\alpha$-GalCer injection, which suggests that DC alterations have very little, if any, impact on NKT cell unresponsiveness. In sharp contrast, NKT cells from mice injected with $\alpha$-GalCer 3 days, 7 days, or 1 month earlier were profoundly hyporesponsive to $\alpha$-GalCer presented by DCs derived from naive or $\alpha$-GalCer-injected mice. To confirm these findings, we adoptively transferred NKT cells from vehicle- or $\alpha$-GalCerinjected mice to naive Ja18-deficient mice, and, 2 weeks later, we measured the response of splenocytes from these animals to stimulation with $\alpha$-GalCer in vitro. Results showed hyporesponsiveness to $\alpha$-GalCer restimulation in mice that received NKT cells from $\alpha$-GalCer-injected mice but normal responses in mice that received NKT cells from vehicle-injected mice (Figure 5B). Taken together, these findings indicate that NKT cell anergy is predominantly NKT cell autonomous and suggest that chronic stimulation with $\alpha$-GalCer is not required for maintenance of the anergic phenotype.

Anergic NKT cells lack bystander suppression. In some forms of $\mathrm{T}$ cell tolerance, the unresponsive phenotype is dominant, leading to bystander suppression of neighboring cells (39). We therefore tested whether anergic NKT cells can suppress the response of naive NKT cells to $\alpha$-GalCer. For this purpose, we mixed splenocytes from naive and $\alpha$-GalCer-injected mice at different ratios and monitored proliferative and cytokine responses to $\alpha$-GalCer stimulation. Results showed that anergic NKT cells fail to suppress responses of naive NKT cells to $\alpha$-GalCer (Figure 5C), providing evidence for lack of bystander suppression. Consistent with this finding, we were unable to detect expression of the transcription factor Foxp3, a molecular correlate of regulatory $\mathrm{T}$ cell function (39), in anergic NKT cells (data not shown).

Role of different APCs and cytokines in $\alpha$-GalCer-induced NKT cell anergy. Next, we investigated the mechanism by which $\alpha$-GalCer induces NKT cell anergy. In conventional $\mathrm{T}$ cells, antigen recognition in the context of no costimulatory signals or insufficient 


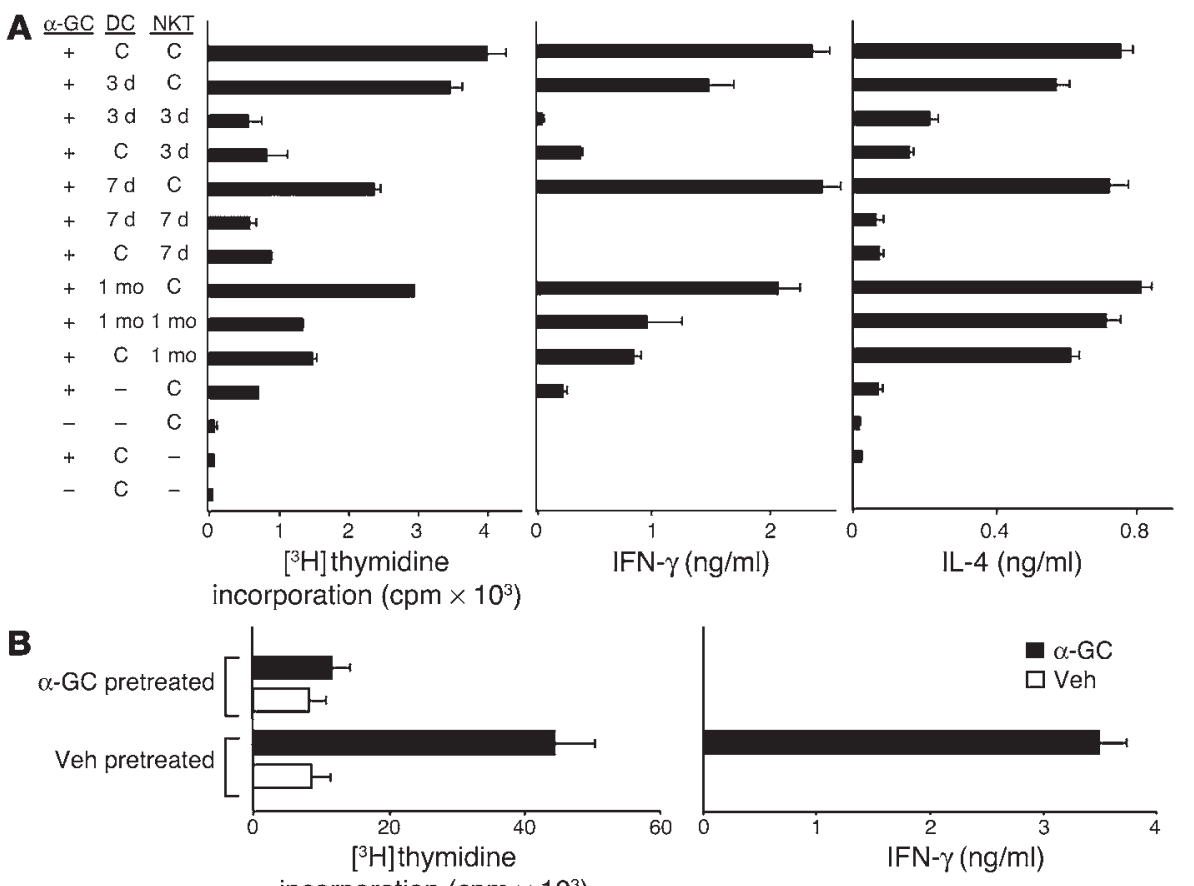

incorporation $\left(\mathrm{cpm} \times 10^{3}\right)$

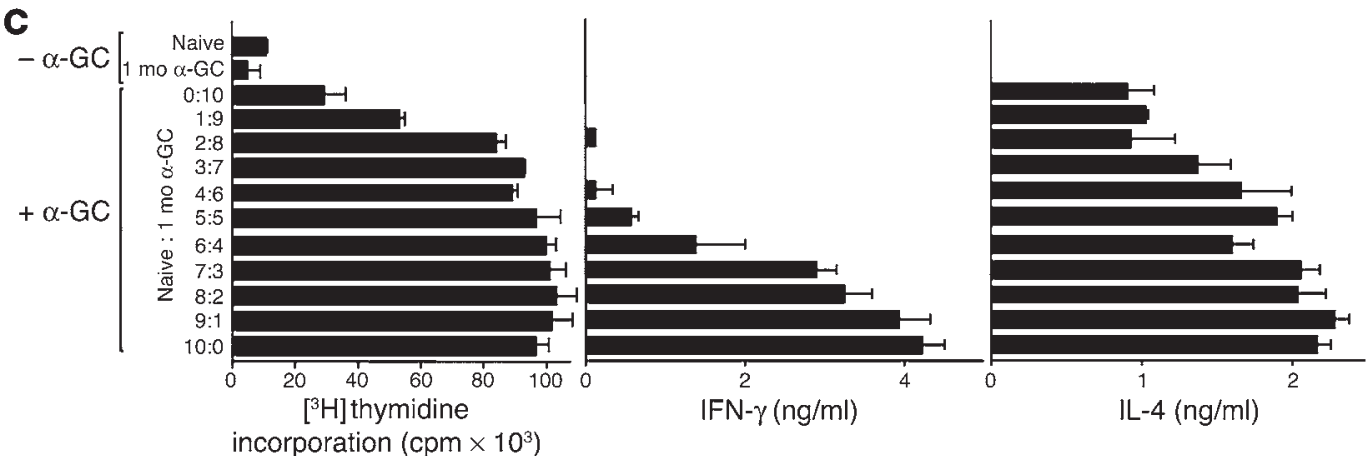

Figure 5

NKT cell anergy is cell autonomous and does not exhibit dominant suppression. (A) NKT cell anergy is predominantly cell autonomous. Mice were injected with $\alpha$-GalCer and sacrificed at 0 days (control [C]), 3 days, 7 days, or 1 month. DCs from the spleen and NKT cells from the liver were then enriched as described in Methods. NKT cells $\left(1 \times 10^{5}\right.$ per well $)$ and DCs $\left(2 \times 10^{4}\right.$ per well $)$ were then cultured in different combinations in the presence $(+)$ or absence $(-)$ of $\alpha$-GalCer. Proliferation was assessed by $\left[{ }^{3} \mathrm{H}\right]$ thymidine incorporation, and IL-4 and IFN- $\gamma$ levels in the supernatant were evaluated by ELISA. (B) NKT cells remain anergic upon adoptive transfer. Mice were injected with $\alpha$-GalCer or vehicle and sacrificed on day 3 . NKT cells were enriched as described in Methods, and $1 \times 10^{7}$ cells were adoptively transferred into irradiated $J \alpha 18^{-/-}$mice. Two weeks later, mice were sacrificed; splenocytes, normalized for numbers of NKT cells, were stimulated with vehicle or $\alpha$-GalCer; and then proliferative and cytokine responses were measured. No IL-4 was detected in any of the cultures. Data represent the average of 3 mice per group. (C) Anergic NKT cells fail to exhibit dominant suppression. Spleen cells from naive mice and from mice injected 1 month earlier with $\alpha$-GalCer were mixed at the indicated ratios and cultured with $\alpha$-GalCer $(100 \mathrm{ng} / \mathrm{ml})$, and then proliferative and cytokine responses were measured. Proliferation results represent the mean \pm SEM of triplicate wells, and cytokine results represent the mean \pm SEM of duplicate wells. Representative data of 3 individual experiments are shown.

costimulatory signals can induce anergy (30). We therefore compared the ability of DCs and B cells, which express high and low levels of costimulatory molecules, respectively, to induce NKT cell anergy. For this purpose, we purified DCs and B cells from the spleens of naive mice, pulsed these cells with $\alpha$-GalCer, injected them in naive animals, and tested mice 15 days later for in vitro responses to $\alpha$-GalCer. Because DCs are more potent than B cells in activating in vivo NKT cell responses (40), we selected numbers of $\alpha$-GalCer-pulsed DCs $\left(6 \times 10^{5}\right)$ and B cells $\left(5 \times 10^{6}\right)$ that induced similar levels of NKT cell activation in vivo, as assessed by downregulation of the invariant TCR and NK1.1, and by induction of
CD69 expression on NKT cells (data not shown). Consistent with prior studies (21), $\alpha$-GalCer-loaded DCs did not induce NKT cell anergy (Figure 6A). In sharp contrast, however, $\alpha$-GalCer-loaded $\mathrm{B}$ cells potently induced NKT cell anergy. These findings suggest that presentation of $\alpha$-GalCer by distinct APCs, exhibiting different capacity to activate NKT cells in vivo, plays a role in $\alpha$-GalCer-induced NKT cell anergy.

Next, we tested the role of cytokines in the induction of NKT cell anergy. For this purpose, we evaluated the capacity of $\alpha$-GalCer to induce NKT cell anergy in mice that were deficient in IL-4, IL-10, or IFN- $\gamma$. Results indicated that, like NKT cells from WT mice, NKT 


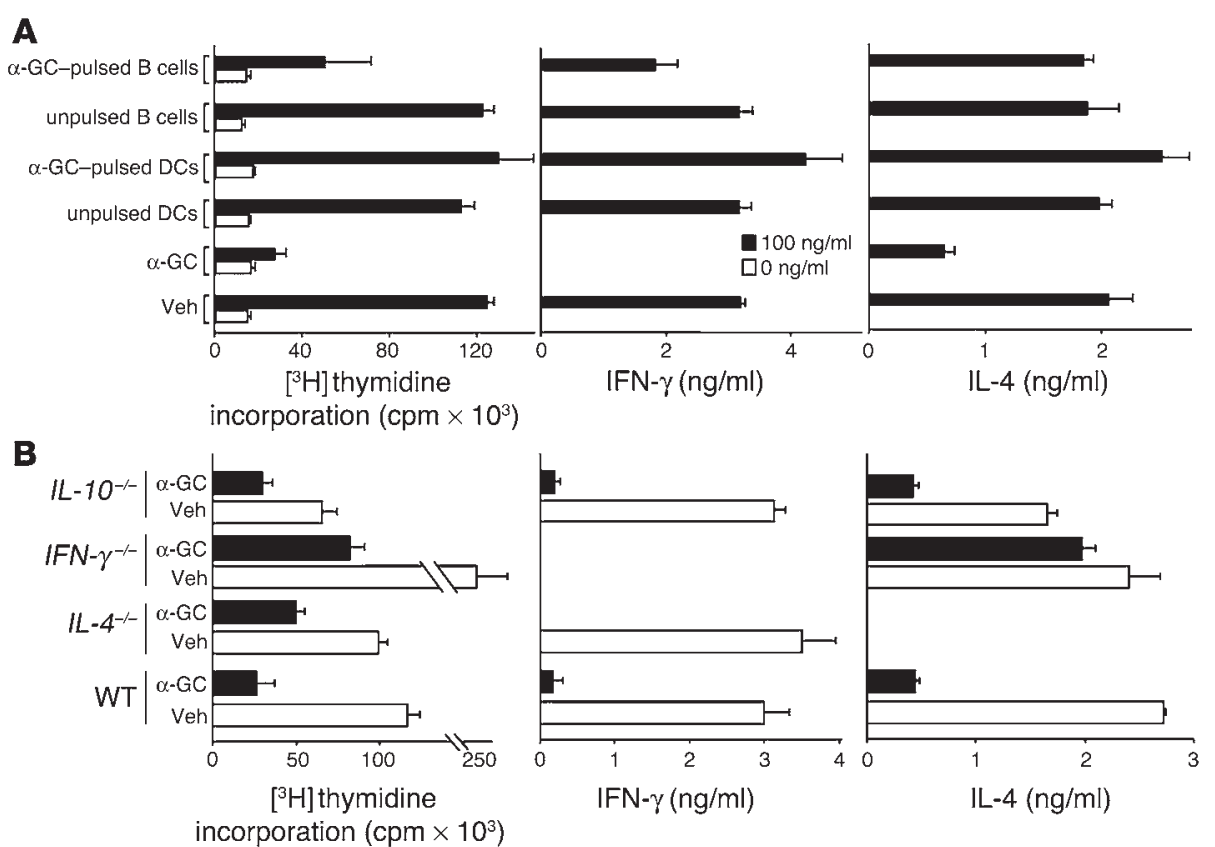

\section{Figure 6}

Role of distinct APCs and cytokines in the induction of NKT cell anergy. (A) Role of distinct APCs. Mice were treated with $\alpha$-GalCer-pulsed or -unpulsed DCs $\left(6 \times 10^{5}\right.$ cells per mouse, i.v. $)$ or B cells $\left(5 \times 10^{6}\right.$ cells per mouse, i.v. $)$ and sacrificed 15 days later, and spleen cells were restimulated with or without $\alpha$-GalCer (100 ng/ml). Proliferation was assessed by $\left[{ }^{3} \mathrm{H}\right]$ thymidine incorporation, and IL-4 and IFN- $\gamma$ levels in the supernatant were evaluated by ELISA. Results shown represent the mean \pm SEM of 4 mice in each group and are representative of 2 individual experiments. (B) Role of cytokines. WT B6, IL-10-/-, IFN- $\gamma^{-/-}$, and $I L-4^{-/}$mice were injected with $\alpha-G a l C e r$ or vehicle, sacrificed 15 days later, and analyzed as in A. Results shown represent the mean \pm SEM of 2 mice in each group. cells from $\alpha$-GalCer-treated $I L-4^{-/-}$and $I L-10^{-/-}$mice were hyporesponsive in terms of proliferation and cytokine secretion to in vitro restimulation with $\alpha$-GalCer (Figure 6B). For IFN- $\gamma$-deficient mice, we observed significantly suppressed proliferative responses, but little effect on IL-4 production (Figure 6B), which may be due to the increased in vitro and in vivo proliferative responses of splenocytes to $\alpha$-GalCer that we have observed in these animals (Figure 6B). Nevertheless, in vivo analysis of the responses of NKT cells from $\alpha$-GalCer-injected IFN- $\gamma$ knockout mice to $\alpha$-GalCer rechallenge confirmed that these cells are anergic (Supplemental Figure 3).

Role of $T$ and $N K$ cell receptors in the maintenance of NKT cell anergy. Prior studies have shown that activation of NKT cells results in the rapid downregulation of TCR and NK1.1 expression (26-28). In addition, repeated administration of $\alpha$-GalCer to mice results in the accumulation of NKT cells expressing enhanced levels of inhibitory Ly49 receptors (32). Therefore, we determined whether alterations in surface expression of these receptors contribute to the maintenance of NKT cell anergy in $\alpha$-GalCer-injected mice. We found that anergic NKT cells expressed slightly reduced levels of surface TCRs (Figure 7A), which is consistent with their reduced sensitivity to TCR engagement. Moreover, we found that $\alpha$-GalCer injection induced sustained downregulation of NK1.1 on NKT cells, which persisted for at least 6 months (Figure 7B). Results for Ly49 expression indicated a transient increase in Ly49 surface expression on both spleen and liver NKT cells at 8 and 24 hours after $\alpha$-GalCer injection, after which expression by most NKT cells returned to normal levels (Figure 7C). No changes in Ly49 receptor expression were observed in the thymus (data not shown). To further investigate the role of classical MHC class I-specific inhibitory receptors in the induction of NKT cell anergy, we evaluated the capacity of $\alpha$-GalCer to induce NKT cell anergy in $T A P^{-1-}$ mice. Results showed that $\alpha$-GalCer can effectively induce NKT cell anergy in these animals (Figure 7D). Collectively, these results indicate that modulation of TCR and NK1.1 expression, but not Ly49 receptor expression, may play a role in maintaining NKT cell anergy. Our studies with TAP-deficient mice also indicate that alterations in the expression of ligands of the nonclassical MHC class I molecule Qa-1 ${ }^{\mathrm{b}}$, which have been suggested to modulate NKT cell responses (41), are not responsible for the anergic phenotype of NKT cells.

Exogenous IL-2 overcomes $\alpha$-GalCer-induced NKT cell anergy. For conventional $\mathrm{T}$ cells, anergy can often be broken by culture with cytokines such as IL-2 (30). Therefore, we tested the capacity of the cytokines IL-2, IL-4, IL-12, and IFN- $\gamma$ to rescue proliferation of anergic NKT cells in vitro. For this purpose, we labeled splenocytes from naive and $\alpha$-GalCer-treated mice with the CFSE dye, activated these cells with or without $\alpha$-GalCer in the presence or absence of cytokines, and evaluated the CFSE dilution profile of tetramer ${ }^{+} \mathrm{NKT}$ cells. For naive mice, culture in plain medium resulted in a low level of NKT cell proliferation (Figure 8A), which is consistent with prior studies (35). Culture of splenocytes from naive mice with $\alpha$-GalCer in the presence or absence of cytokines resulted in profound NKT cell proliferation. In sharp contrast, and consistent with our findings above (Figure 2, A and B), NKT cells from the $\alpha$-GalCer-treated group failed to proliferate in plain medium or in response to $\alpha$-GalCer (Figure 8A). Addition of IL-2, but not IL-4, IL-12, or IFN- $\gamma$, was able to overcome this blockade in NKT cell proliferation. IL-2 was also able to break NKT cell anergy in vivo, as revealed by its capacity to restore $\alpha$-GalCer-induced NKT cell expansion in mice injected 1 month earlier with $\alpha$-GalCer (Figure $8 \mathrm{~B}$ ). In sharp contrast, however, CFA was unable to break NKT cell anergy. Thus, NKT cell anergy can be overcome by IL-2, both in vitro and in vivo.

\section{Discussion}

NKT cells are an unusual group of lymphocytes that share receptor structures and functions with cells of both the innate and the adaptive immune systems (1-7). The response of invariant NKT cells to TCR engagement has been studied most extensively with the CD1d-presented, sponge-derived glycolipid $\alpha$-GalCer. Until recently, however, it was thought that in vivo administration of $\alpha$-GalCer results in the rapid death of NKT cells, followed by repopulation from a pool of proliferating cells in the bone marrow (23-25). It is now clear that the disappearance of NKT cells around 8-24 

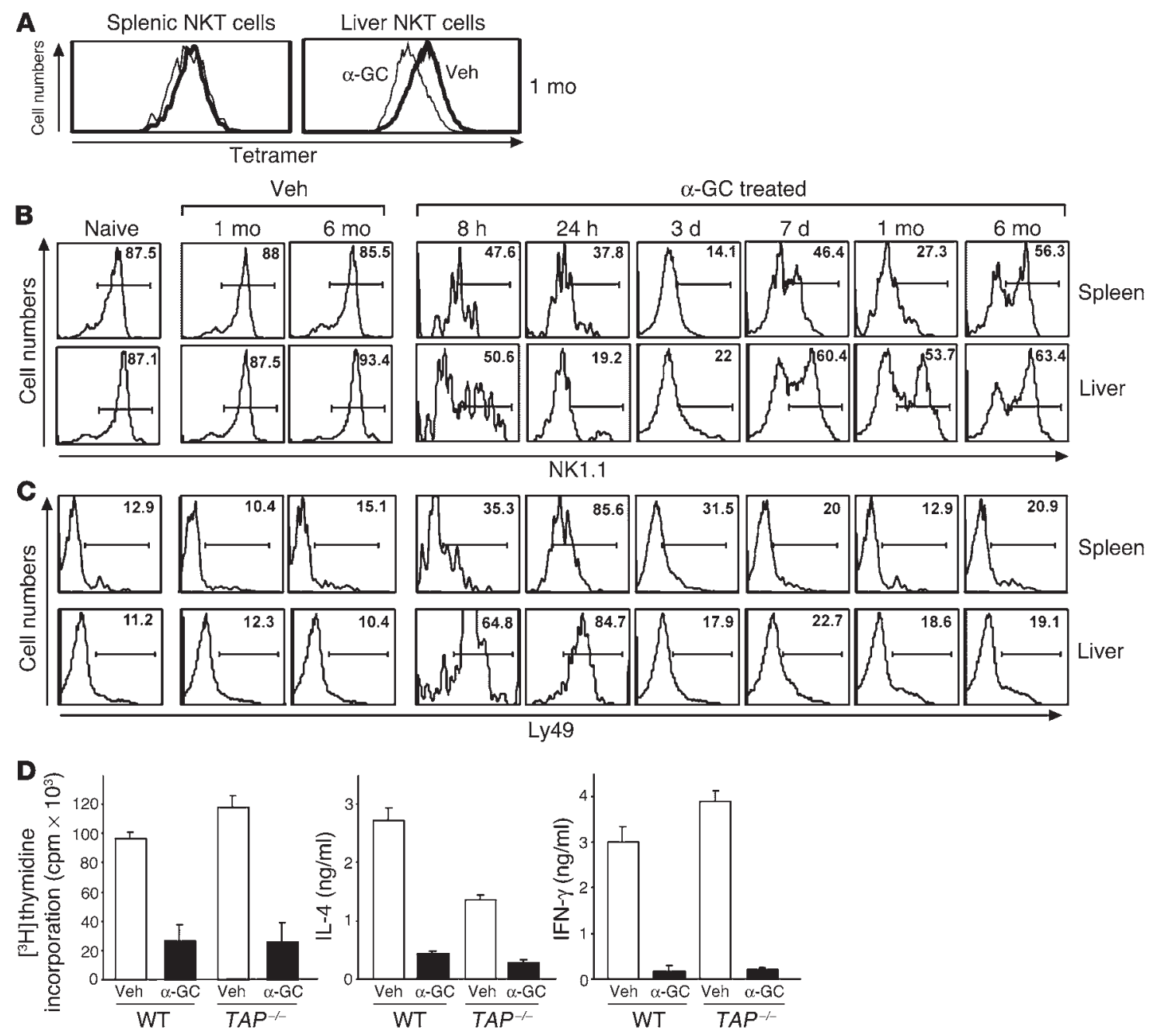

\section{Figure 7}

Role of TCR, NK1.1, and Ly49 expression in the maintenance of NKT cell anergy. (A-C) Surface expression of TCR, NK1.1, and Ly49 molecules. Mice were injected with $\alpha$-GalCer or vehicle, and spleen and liver cells were prepared at the indicated time points. Cells were stained with anti-TCR- $\beta$ FITC or -allophycocyanin, tetramer-PE, anti-B220-PerCP, and anti-NK1.1-allophycocyanin or a cocktail of FITC-labeled anti-Ly49 antibodies, and analyzed by flow cytometry. Levels of TCR expression on B220 tetramer+ cells (A), NK1.1 expression on B220-TCR- $\beta{ }^{+}$tetramer ${ }^{+}$cells (B), and Ly49 expression on B220-TCR- $\beta^{+}$tetramer ${ }^{+}$cells (C) were evaluated. Data are representative of 4 independent experiments with 2 mice in each group. (D) Induction of NKT cell anergy in mice lacking classical MHC class I molecules. WT B6 and TAP ${ }^{-1-}$ mice were injected with $\alpha$-GalCer or vehicle. Fifteen days later, spleen cells were prepared and restimulated in vitro with $\alpha$-GalCer (100 ng/ml). Proliferative and cytokine responses were evaluated as in Figure 1. Results shown represent the mean \pm SEM of 2 mice in each group and are representative of 2 individual experiments.

hours following $\alpha$-GalCer administration is due to profound TCR downregulation, which renders these cells undetectable by CD1d tetramers (26-28). Instead, most NKT cells stay alive and rapidly expand in spleen, liver, bone marrow, and peripheral blood, reaching maximal levels around 3 days after $\alpha$-GalCer administration $(26,27)$. Most NKT cells then die by apoptosis, leading to a rapid decline in numbers and reaching homeostatic levels around days $7-10$ after a single i.p. injection of $5 \mu \mathrm{g} \alpha$-GalCer. Here, we have further shown that NKT cell numbers continue to decline in the spleen until at least 6 months after $\alpha$-GalCer administration, suggesting that NKT cells from $\alpha$-GalCer-treated mice are more prone to undergo apoptosis than NKT cells from naive or vehicle-injected mice. In addition, we found that the remaining NKT cells in $\alpha$-GalCer-injected mice are functionally unresponsive to $\alpha$-GalCer restimulation for at least 30 days after $\alpha$-GalCer administration.
Anergic NKT cells were hyporesponsive in terms of their capacity to proliferate, produce cytokines, transactivate other cell types, and prevent B16 tumor metastasis formation. Thus, a single injection of $\alpha$-GalCer tolerizes NKT cells to future responses to this glycolipid by peripheral anergy. A likely physiological reason for induction of an anergic response in NKT cells to glycolipid stimulation is to avoid excessive inflammation and tissue destruction.

A recent study has shown that repeated injection of $\alpha$-GalCer results in depletion of NKT cells and the emergence of new thymic NKT cell emigrants that express increased levels of self-reactive inhibitory receptors, as a result of chronic exposure of thymocytes to $\alpha$-GalCer (32). However, we did not observe such an increase in MHC class I-specific Ly49 expression in the spleen, liver, or thymus (data not shown) of mice injected with a single dose of $\alpha$-GalCer. In addition, we obtained similar results in thymecto- 
A

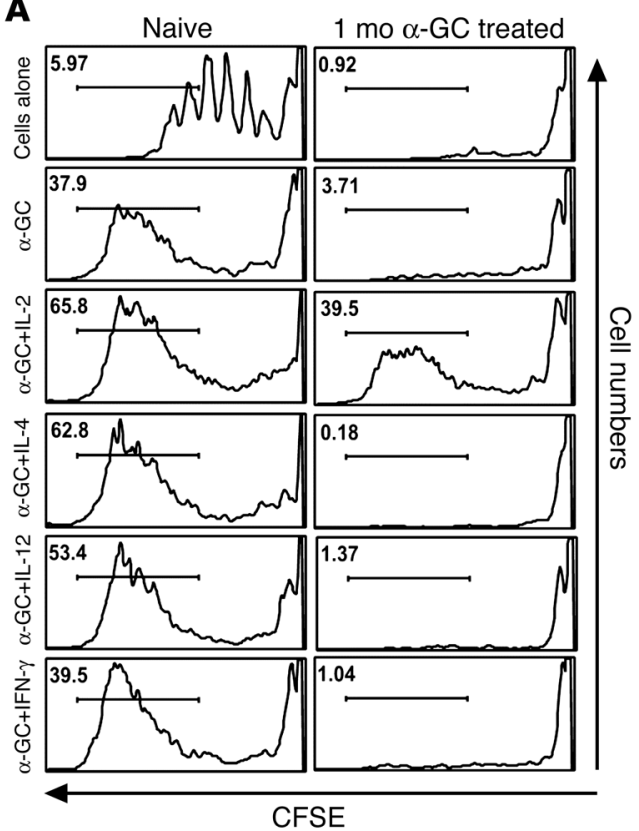

B
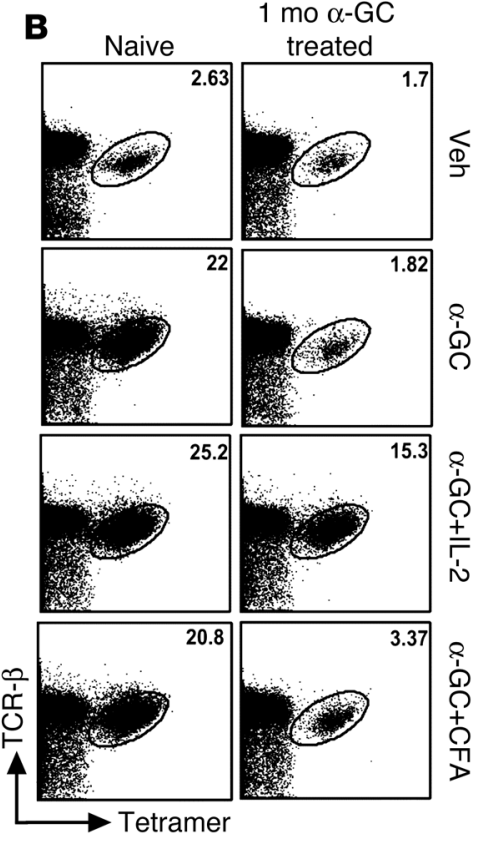

Figure 8

Exogenous IL-2 overcomes NKT cell anergy. (A) IL-2 overcomes NKT cell anergy in vitro. Spleen cells from naive mice or from mice injected 1 month earlier with $\alpha$-GalCer were labeled with CFSE. Cells $\left(2 \times 10^{5}\right.$ per well) were then cultured with $\alpha$-GalCer $(100 \mathrm{ng} / \mathrm{ml})$ for 24 hours in the presence or absence of IL-2, IL-4, IL-12, or IFN- $\gamma(2.5-10 \mathrm{ng} / \mathrm{ml})$. Cells were then washed and cultured for an additional 96 hours without $\alpha$-GalCer in the presence or absence of the respective cytokines. At the end of the culture period, cells were harvested, stained with tetramer-PE and anti-B220-PerCP, and analyzed by flow cytometry. CFSE dilution was analyzed on B220-tetramer ${ }^{+}$cells. A representative experiment of 3 independent experiments, using a cytokine concentration of $10 \mathrm{ng} / \mathrm{ml}$, is shown. (B) IL-2 overcomes NKT cell anergy in vivo. Naive mice or mice injected with $\alpha$-GalCer 1 month earlier were injected with vehicle, $\alpha$-GalCer, $\alpha$-GalCer plus IL-2 (500 ng, i.p.), or $\alpha$-GalCer plus CFA (200 $\mu$ g, s.c.). Three days later, mice were sacrificed, and NKT cell expansion was evaluated in the spleen by flow cytometry. Data are representative of results for 3 mice per group.

mized mice (data not shown), providing strong evidence that NKT cell anergy following a single dose of $\alpha$-GalCer is induced in the periphery, rather than in the thymus. Thus, distinct mechanisms induce NKT cell anergy following a single injection of $\alpha$-GalCer and following chronic $\alpha$-GalCer administration.

Previous studies investigating the response to $\alpha$-GalCer have shown that, in sharp contrast to free $\alpha$-GalCer, $\alpha$-GalCer-loaded DCs do not induce a blunted recall response to $\alpha$-GalCer in mice (21). We have confirmed and extended these findings, showing that $\alpha$-GalCer-pulsed B cells do induce NKT cell unresponsiveness. These findings support the idea that presentation of $\alpha$-GalCer by distinct APCs plays a role in the induction of NKT cell anergy. Whether these differential responses of NKT cells to stimulation by distinct APCs are due to differences in the expression of costimulatory molecules or other factors by APCs remains to be explored.

Our findings provide evidence that NKT cell anergy is largely cell autonomous and can be induced in $I F N-\gamma, I L-4$, and $I L-10$ mutant mice, excluding a requirement for each of these cytokines in the induction and maintenance of NKT cell anergy. The anergic phenotype of NKT cells correlated with slightly reduced TCR and substantially reduced NK1.1 expression. However, reduced TCR expression by itself cannot explain the anergic phenotype, because increased doses of $\alpha$-GalCer used during the recall response were dependence on costimulation are consistent with adaptive tolerance. Further studies will be required to determine whether the NKT cell anergy studied here is more similar to clonal anergy or adaptive tolerance described for conventional $\mathrm{T}$ cells.

Based on our findings, and together with prior studies $(26,27$, 32 ), the picture is now emerging that $\alpha$-GalCer induces rapid NKT cell expansion in mice, followed by homeostatic cell death and anergy. This response of NKT cells to $\alpha$-GalCer is reminiscent of the response of conventional $\mathrm{T}$ cells to strong stimuli such as superantigens (42-44). Both $\alpha$-GalCer and superantigen induce strong TCR-mediated signals. However, one important difference between these reagents is that $\alpha$-GalCer binds with the CD1d groove (4-6) whereas superantigen cross-links MHC class II and certain TCR $\mathrm{V} \beta$ chains (45). In addition, NKT cells bear a semi-invariant TCR, whereas superantigen-specific T cells express diverse TCRs.

$\alpha$-GalCer holds significant promise for prevention or treatment of a variety of pathologies $(5,6,46-49)$. In most of these treatment protocols, multiple doses of $\alpha$-GalCer have been administered. Our findings indicate that, after a single dose of free $\alpha$-GalCer, NKT cells become unresponsive to restimulation, raising questions regarding the mechanism by which $\alpha$-GalCer modulates disease. Interestingly, we found that $\alpha$-GalCer was unable to prevent the development of B16 lung metastases in mice that had 
been treated 1 month earlier with a single dose of $\alpha$-GalCer. Prior studies have shown that IFN- $\gamma$, produced by NKT and NK cells, is critically important for the capacity of $\alpha$-GalCer to prevent B16 tumor metastases (37). Therefore, the most likely explanation for defective clearance of metastatic tumors in $\alpha$-GalCer-pretreated animals is that anergic NKT cells, upon restimulation with $\alpha$-GalCer, fail to produce IFN- $\gamma$ and its induction by NK cells. Our finding that $\alpha$-GalCer actually exacerbates B16 nodule formation in the lungs of $\alpha$-GalCer-pretreated animals may be related to alterations in the cytokine production profile of anergic NKT cells and requires further investigation. In sharp contrast to our metastasis studies, $\alpha$-GalCer retained its capacity to prevent EAE induction in $\alpha$-GalCer-pretreated animals. Because IL- 4 plays a critical role in the capacity of $\alpha$-GalCer to protect mice against $\operatorname{EAE}(14,15)$, a likely explanation for the latter finding is that NKT cells from $\alpha$-GalCer-injected mice, in large part, retain their capacity to produce IL-4. In this regard, our studies with thymectomized mice (data not shown) suggest that NKT cells that newly emerged from the thymus, which have an IL-4-biased cytokine profile $(33,34)$, may contribute to this residual IL-4 production.

In summary, we have found that a single injection of $\alpha$-GalCer induces long-term NKT cell hyporesponsiveness in mice. These findings should be taken into consideration in the design of NKT cell-based vaccines and immunotherapies.

\section{Methods}

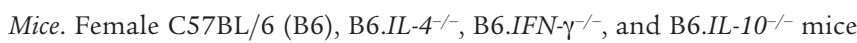
were purchased from the Jackson Laboratory, B6.CD1 $d^{-/-}$mice (50) and B6.TAP ${ }^{-/}$mice (51) have been described, B6.J $\alpha 18^{-/-}$mice (52) were obtained from M. Taniguchi (RIKEN Research Center for Allergy and Immunology, Yokohama, Japan), and B6.I-A $\mathrm{b}^{-/-}$(class II-/-) mice were obtained from D. Mathis and C. Benoist (Harvard Medical School, Boston, Massachusetts, USA). All animal studies were approved by the Institutional Animal Care and Use Committee of Vanderbilt University.

Reagents. $\alpha$-GalCer (KRN7000) was obtained from Kirin Brewery Co. and was reconstituted in PBS containing $0.5 \%$ polysorbate-20 (SigmaAldrich). Fluorescently labeled tetrameric CD1d molecules loaded with $\alpha$-GalCer (CD1d tetramers) were prepared as described previously (31, 53 ). Anti-TCR- $\beta$-FITC and -allophycocyanin, anti-NK1.1-PE and -allophycocyanin, anti-Ly49A-FITC, anti-Ly49C/I-FITC, anti-Ly49D-FITC, anti-Ly49G2-FITC, anti-B220-peridinin chlorophyll protein (anti-B220PerCP), anti-CD3-PerCP, anti-IL-4-allophycocyanin, anti-IFN- $\gamma$-FITC, anti-CD69-FITC, anti-CD11c-allophycocyanin, anti-CD80-FITC, antiCD86-PE, anti-CD40L-biotin, and streptavidin-PE-cyanide dye 5 were obtained from BD Biosciences - Pharmingen. Recombinant IL-2, IL-4, IL-12, and IFN- $\gamma$ were also obtained from BD Biosciences - Pharmingen, PMA and ionomycin from ICN Pharmaceuticals Inc., CFA from BD Biosciences, and CFSE from Invitrogen Corp.

Flow cytometry. Single-cell suspensions of the spleen and liver were prepared and stained with fluorescently labeled $\mathrm{mAbs}$ as described previously (35). In all experiments, dead cells were excluded from the analysis by electronic gating. The NKT cell population was identified as B220-TCR$\beta^{+}$tetramer ${ }^{+}$cells. For analysis of intracellular cytokines of NKT and NK cells, $2 \times 10^{5}$ splenocytes were activated with $\alpha$-GalCer or PMA $(20 \mathrm{ng} /$ $\mathrm{ml})$ plus ionomycin $(1 \mu \mathrm{M})$ for 6 hours in U-bottomed 96-well plates. Intracellular cytokine staining was performed with Cytofix/Cytoperm reagents (BD Biosciences - Pharmingen) according to the manufacturer's protocol. For staining of DCs, Fc receptors were first blocked by addition of anti-CD16/32 antibodies (BD Biosciences - Pharmingen), and DCs were identified on the basis of high CD11c expression. Flow cytometry was performed using a FACSCalibur instrument (BD), and the acquired data were analyzed using FlowJo software (Tree Star Inc.).

Measurement of in vivo and in vitro responses to $\alpha$-GalCer. Mice were injected i.p. with $5 \mu \mathrm{g} \alpha$-GalCer in $200 \mu \mathrm{l}$ PBS containing $0.025 \%$ polysorbate- 20 (vehicle). At different time points, mice were bled and cytokines were measured in the serum. Alternatively, mice were sacrificed, spleens were harvested, and single-cell suspensions were prepared. Cells were then stained with fluorescently labeled mAbs and analyzed by flow cytometry. Alternatively, spleen cell suspensions were plated in U-bottomed 96-well plates at $2 \times 10^{5}$ cells per well in RPMI medium containing $10 \%$ FCS (R-10) in the presence of titrated doses of glycolipids or vehicle. For proliferation assays, $1 \mu \mathrm{Ci}$ of $\left[{ }^{3} \mathrm{H}\right]$ thymidine (PerkinElmer Life Sciences) was added to the wells after 60 hours of culture, and cells were cultured for an additional 12 hours. Cells were then harvested, and uptake of radioactivity was measured. For measurement of cytokine secretion in vitro, supernatants were harvested after 60 hours of culture, and cytokine levels were evaluated by ELISA. The activation status of NKT cells, NK cells, B cells, conventional $\mathrm{T}$ cells, and DCs was assessed at different time points after $\alpha$-GalCer or vehicle treatment by staining with $\mathrm{mAbs}$ directed against activation markers, followed by flow cytometry.

ELISA. A standard sandwich ELISA was performed to measure mouse IFN- $\gamma$, IL-4, and IL-12 p70 levels. IFN- $\gamma$ - and IL-4-paired antibodies were obtained from R\&D Systems Inc., and IL-12-paired antibodies and all cytokine standards were obtained from BD Biosciences - Pharmingen. For detection, streptavidin-HRP conjugate (Zymed Laboratories Inc.) was used, and the color was developed with the substrate 3,3',5,5'-tetramethylbenzidine (Dako Corp.) in the presence of $\mathrm{H}_{2} \mathrm{O}_{2}$.

NKT cell enrichment and adoptive transfer experiments. For the experiment in Figure 5A, livers were perfused with cold PBS and then pressed through a $70-\mu \mathrm{m}$ cell strainer. Cells were suspended in $40 \mathrm{ml}$ RPMI medium in a $50-\mathrm{ml}$ conical tube and allowed to stand on ice for 45 minutes. The supernatant was then centrifuged, resuspended in cold $40 \%$ Percoll (Amersham Biosciences Corp.), and underlaid with 60\% Percoll. Cells were centrifuged at $1,500 \mathrm{~g}$ for 20 minutes at $4{ }^{\circ} \mathrm{C}$. Mononuclear cells at the interphase of the $40 \%$ and $60 \%$ Percoll solutions were collected and washed twice with RPMI medium containing $10 \%$ FCS (R-10). Liver mononuclear cells included $25-30 \%$ NKT cells as determined by tetramer staining. Two rounds of panning, 2 hours each, were then carried out to remove plastic-adherent APCs.

For the adoptive transfer experiments in Figure 5B, MHC class II-null mice were injected with vehicle or $\alpha$-GalCer. Three days later, mice were sacrificed, and NKT cells were enriched by negative magnetic sorting (Miltenyi Biotec) using anti-B220, -CD11b, -CD11c, and -CD8 $\alpha$ antibodies. Enriched NKT cells $\left(1 \times 10^{7}\right.$ per mouse; $78-85 \%$ purity as determined by tetramer staining) were injected i.v. into irradiated (7.5 Gy) $J \alpha 18^{-/-}$mice. Two weeks later, mice were sacrificed, and spleen and liver cells were analyzed by flow cytometry for NKT cell reconstitution, which was between $1.2 \%$ and $3.1 \%$ of all lymphocytes in spleen and between $15 \%$ and $35 \%$ of all lymphocytes in liver.

Isolation of splenic DCs and B cells. Spleens were cut into small pieces and digested with $0.2 \mathrm{mg} / \mathrm{ml}$ collagenase D (Roche Diagnostics Corp.) in FCS-free RPMI medium for 45 minutes. The digestion was terminated by addition of cold R-10 medium. DCs were enriched based on expression of the CD11c marker, whereas B cells were enriched on the basis of B220 expression, by magnetic sorting (Miltenyi Biotec) according to the manufacturer's protocol. Purity of enriched cell populations was $85-90 \%$ for DCs and greater than $97 \%$ for B cells (data not shown). For the experiment in Figure 6A, purified DCs and B cells were pulsed for 3 hours with 200 $\mathrm{ng} / \mathrm{ml} \alpha$-GalCer at $37^{\circ} \mathrm{C}$. Cells were then washed 3 times in R-10 medium to remove excess $\alpha$-GalCer, and injected i.v. into B6 mice $\left(6 \times 10^{5} \mathrm{DCs}\right.$ or 
$5 \times 10^{6} \mathrm{~B}$ cells per mouse). Mice were sacrificed 15 days later for analysis of NKT cell function.

CFSE dilution analysis. Whole splenocytes were labeled with $1 \mu \mathrm{M}$ CFSE for 15 minutes at $37^{\circ} \mathrm{C}$ in PBS containing $5 \% \mathrm{FCS}$, and washed twice with R-10 medium. Labeled splenocytes $\left(2 \times 10^{5}\right.$ cells per well $)$ were then stimulated with $\alpha$-GalCer $(100 \mathrm{ng} / \mathrm{ml})$ with or without addition of cytokines $(2.5-10 \mathrm{ng} / \mathrm{ml})$ for 24 hours in R-10 medium. Cells were washed 3 times with R-10 medium and cultured for an additional 96 hours in R-10 medium containing the respective cytokines without $\alpha$-GalCer. At the end of the culture, cells were harvested, stained with PE-labeled CD1d tetramer and anti-B220-PerCP, and analyzed by flow cytometry. Dead cells were excluded from the analysis by electronic gating. CFSE dilution analysis was performed on B220-tetramer ${ }^{+}$NKT cells.

Determination of B16 melanoma lung metastases. B6 mice were injected i.v. with $3 \times 10^{5}$ syngeneic B16 melanoma cells suspended in PBS. Mice were treated with $\alpha$-GalCer or vehicle at 0,4 , and 8 days. Fifteen days after challenge, mice were killed, lungs were removed, and the number of metastatic nodules was counted as described previously (21).

Induction and evaluation of EAE. Active EAE in B6 mice was induced as described previously (14). Briefly, 8- to 10-week-old female B6 mice were immunized s.c. with $200 \mu \mathrm{g}$ of $\mathrm{MOG}_{35-55}$ peptide emulsified in CFA (BD Biosciences) on days 0 and 7. Mice also received $250 \mathrm{ng}$ of pertussis toxin (Invitrogen Corp.) i.p. on days 0 and 2. Mice were treated with $5 \mu \mathrm{g}$ of
$\alpha$-GalCer or vehicle on days 0,4 , and 7 by i.p. injection. Clinical symptoms were monitored daily after the first immunization. The clinical score was graded as follows: 0 , no disease; 1 , tail limpness; 2 , hind-limb weakness; 3 , hind-limb paralysis; 4, forelimb weakness; 5 , quadriplegia; and 6 , death.

Statistical analysis. Statistical significance between the groups was determined by application of an unpaired 2-tailed Student's $t$ test. A $P$ value less than 0.05 was considered significant.

\section{Acknowledgments}

We thank Kirin Brewery Co. for providing $\alpha$-GalCer and J. Wei and $\mathrm{T}$. Vincent for technical assistance. This work was supported by NIH grants AI50953, NS44044, and HL68744 (to L. Van Kaer), AI42284 (to S. Joyce), and AI43407 (to C.-R. Wang), and by the Juvenile Diabetes Research Foundation International (to S. Joyce).

Received for publication February 14, 2005, and accepted in revised form June 14, 2005.

Address correspondence to: Luc Van Kaer, Department of Microbiology and Immunology, Room A-5301 Medical Center North, Vanderbilt University School of Medicine, Nashville, Tennessee 37232, USA. Phone: (615) 343-2707; Fax: (615) 343-2972; E-mail: luc.van.kaer@vanderbilt.edu.
1. Bendelac, A., Rivera, M.N., Park, S.H., and Roark, J.H. 1997. Mouse CD1-specific NK1 T cells: development, specificity, and function [review]. Annu. Rev. Immunol. 15:535-562.

2. Godfrey, D.I., Hammond, K.J., Poulton, L.D., Smyth, M.J., and Baxter, A.G. 2000. NKT cells: facts, functions and fallacies [review]. Immunol. Today. 21:573-583.

3. Joyce, S. 2001. CD1d and natural T cells: how their properties jump-start the immune system [review]. Cell. Mol. Life Sci. 58:442-469.

4. Kronenberg, M., and Gapin, L. 2002. The unconventional lifestyle of NKT cells. Nat. Rev. Immunol. 2:557-568.

5. Taniguchi, M., Harada, M., Kojo, S., Nakayama, T., and Wakao, H. 2003. The regulatory role of Va14 NKT cells in innate and acquired immune response. Annu. Rev. Immunol. 21:483-513.

6. Brigl, M., and Brenner, M.B. 2004. CD1: antigen presentation and $\mathrm{T}$ cell function [review]. Annu. Rev. Immunol. 22:817-890.

7. Van Kaer, L. 2004. Regulation of immune responses by CD1d-restricted natural killer T cells. Immunol. Res. 30:139-153.

8. Godfrey, D.I., and Kronenberg, M. 2004. Going both ways: immune regulation via CD1d-dependent NKT cells [review]. J. Clin. Invest. 114:1379-1388. doi:10.1172/JCI200522452

9. Natori, T., Koezuka, Y., and Higa, T. 1993. Agelasphins, novel $\alpha$-galactosylceramides from the marine sponge Agelas mauritianus. Tetrahedron Lett. 34:5591-5592.

10. Hong, S., et al. 2001. The natural killer T-cell ligand $\alpha$-galactosylceramide prevents autoimmune diabetes in non-obese diabetic mice. Nat Med. 7:1052-1056

11. Sharif, S., et al. 2001. Activation of natural killer $\mathrm{T}$ cells by $\alpha$-galactosylceramide treatment prevents the onset and recurrence of autoimmune type 1 diabetes. Nat. Med. 7:1057-1062.

12. Wang, B., Geng, Y.B., and Wang, C.R. 2001 CD1-restricted NK T cells protect nonobese diabetic mice from developing diabetes. J. Exp. Med. 194:313-320.

13. Naumov, Y.N., et al. 2001. Activation of CD1drestricted $\mathrm{T}$ cells protects NOD mice from developing diabetes by regulating dendritic cell subsets.
Proc. Natl. Acad. Sci. U. S. A. 98:13838-13843.

14. Singh, A.K., et al. 2001. Natural killer T cell activation protects mice against experimental autoimmune encephalomyelitis. J. Exp. Med. 194:1801-1811.

15. Jahng, A.W., et al. 2001. Activation of natural killer T cells potentiates or prevents experimental autoimmune encephalomyelitis. J. Exp. Med. 194:1789-1799.

16. Miyamoto, K., Miyake, S., and Yamamura, T. 2001. A synthetic glycolipid prevents autoimmune encephalomyelitis by inducing $\mathrm{TH} 2$ bias of natural killer T cells. Nature. 413:531-534.

17. Osman, Y., et al. 2000. Activation of hepatic NKT cells and subsequent liver injury following administration of $\alpha$-galactosylceramide. Eur. J. Immunol. 30:1919-1928.

18. Ito, K., et al. 2000. Involvement of decidual V $\alpha 14$ NKT cells in abortion. Proc. Natl. Acad. Sci. U. S. A. 97:740-744.

19. Major, A.S., and Van Kaer, L. 2005. The role of natural killer $\mathrm{T}$ cells in atherosclerosis. Current Immunology Reviews. In press.

20. Singh, N., et al. 1999. Cutting edge: activation of NK T cells by CD1d and $\alpha$-galactosylceramide directs conventional $\mathrm{T}$ cells to the acquisition of a Th2 phenotype. J. Immunol. 163:2373-2377.

21. Fujii, S., Shimizu, K., Kronenberg, M., and Steinman, R.M. 2002. Prolonged IFN- $\gamma$-producing NKT response induced with $\alpha$-galactosylceramide-loaded DCs. Nat. Immunol. 3:867-874.

22. Matsuda, J.L., et al. 2003. Mouse V $\alpha 14$ i natural killer $\mathrm{T}$ cells are resistant to cytokine polarization in vivo. Proc. Natl. Acad. Sci. U. S. A. 100:8395-8400.

23. Eberl, G., and MacDonald, H.R. 1998. Rapid death and regeneration of NKT cells in anti-CD3epsilonor IL-12-treated mice: a major role for bone marrow in NKT cell homeostasis. Immunity. 9:345-353.

24. Eberl, G., and MacDonald, H.R. 2000. Selective induction of NK cell proliferation and cytotoxicity by activated NKT cells. Eur. J. Immunol. 30:985-992.

25. Leite-de-Moraes, M.C., et al. 2000. Fas/Fas ligand interactions promote activation-induced cell death of NK T lymphocytes. J. Immunol. 165:4367-4371.

26. Wilson, M.T., et al. 2003. The response of natural killer $\mathrm{T}$ cells to glycolipid antigens is characterized by surface receptor down-modulation and expansion. Proc. Natl. Acad. Sci. U. S. A. 100:10913-10918.
27. Crowe, N.Y., et al. 2003. Glycolipid antigen drives rapid expansion and sustained cytokine production by NKT cells. J. Immunol. 171:4020-4027.

28. Harada, M., et al. 2004. Down-regulation of the invariant V $\alpha 14$ antigen receptor in NKT cells upon activation. Int. Immunol. 16:241-247.

29. Burdin, N., Brossay, L., and Kronenberg, M. 1999. Immunization with $\alpha$-galactosylceramide polarizes CD1-reactive NK T cells towards Th2 cytokine synthesis. Eur. J. Immunol. 29:2014-2025.

30. Schwartz, R.H. 2003. T cell anergy. Annu. Rev. Immunol. 21:305-334.

31. Matsuda, J.L., et al. 2000. Tracking the response of natural killer $\mathrm{T}$ cells to a glycolipid antigen using CD1d tetramers. J. Exp. Med. 192:741-754.

32. Hayakawa, Y., Berzins, S.P., Crowe, N.Y., Godfrey, D.I., and Smyth, M.J. 2004. Antigen-induced tolerance by intrathymic modulation of self-recognizing inhibitory receptors. Nat. Immunol. 5:590-596.

33. Benlagha, K., Kyin, T., Beavis, A., Teyton, L., and Bendelac, A. 2002. A thymic precursor to the NK T cell lineage. Science. 296:553-555.

34. Pellicci, D.G., et al. 2002. A natural killer T (NKT) cell developmental pathway involving a thymusdependent NK1.1-CD4+ CD1d-dependent precursor stage. J. Exp. Med. 195:835-844.

35. Parekh, V.V., et al. 2004. Quantitative and qualitative differences in the in vivo response of NKT cells to distinct $\alpha$ - and $\beta$-anomeric glycolipids. J. Immunol. 173:3693-3706.

36. Carnaud, C., et al. 1999. Cutting edge: crosstalk between cells of the innate immune system: NKT cells rapidly activate NK cells. J. Immunol. 163:4647-4650.

37. Wilson, M.T., and Van Kaer, L. 2003. Natural killer $\mathrm{T}$ cells as targets for therapeutic intervention in autoimmune diseases. Curr. Pharm. Des. 9:201-220.

38. Steinman, R.M., Hawiger, D., and Nussenzweig, M.C. 2003. Tolerogenic dendritic cells. Annu. Rev. Immunol. 21:685-711.

39. Shevach, E.M. 2002. CD4 ${ }^{+} \mathrm{CD}_{25} 5^{+}$suppressor T cells: more questions than answers [review]. Nat. Rev. Immunol. 2:389-400.

40. Bezbradica, J.S., et al. 2005. Distinct roles of dendritic cells and B cells in Va14Ja18 natural T cell activation in vivo. J. Immunol. 174:4694-4705.

41. Ota, T., et al. 2005. IFN- $\gamma$-mediated negative feed- 
back regulation of NKT cell function by CD94/ NKG2. Blood. 106:184-192.

42. Webb, S., Morris, C., and Sprent, J. 1990. Extrathymic tolerance of mature T cells: clonal elimination as a consequence of immunity. Cell. 63:1249-1256.

43. Rammensee, H.G., Kroschewski, R., and Frangoulis, B. 1989. Clonal anergy induced in mature V $\beta 6$ $\mathrm{T}$ lymphocytes on immunizing $M l s-1^{\mathrm{b}}$ mice with $M l s-1^{\text {a }}$ expressing cells. Nature. 339:541-544.

44. Hildeman, D.A., Zhu, Y., Mitchell, T.C., Kappler, J., and Marrack, P. 2002. Molecular mechanisms of activated $\mathrm{T}$ cell death in vivo. Curr. Opin. Immunol. 14:354-359.

45. Li, H., Llera, A., Malchiodi, E.L., and Mariuzza, R.A. 1999. The structural basis of T cell activation by superantigens. Annu. Rev. Immunol. 17:435-466.
46. Wilson, M.T., Singh, A.K., and Van Kaer, L. 2002. Immunotherapy with ligands of natural killer $\mathrm{T}$ cells. Trends Mol. Med. 8:225-231.

47. Van Kaer, L. 2005. $\alpha$-Galactosylceramide therapy for autoimmune diseases: prospects and obstacles [review]. Nat. Rev. Immunol. 5:31-42.

48. Fujii, S., Shimizu, K., Smith, C., Bonifaz, L., and Steinman, R.M. 2003. Activation of natural killer $\mathrm{T}$ cells by $\alpha$-galactosylceramide rapidly induces the full maturation of dendritic cells in vivo and thereby acts as an adjuvant for combined CD 4 and CD8 T cell immunity to a coadministered protein. J. Exp. Med. 198:267-279.

49. Hermans, I.F., et al. 2003. NKT cells enhance CD4+ and $\mathrm{CD}^{+} \mathrm{T}$ cell responses to soluble antigen in vivo through direct interaction with dendritic cells.
J. Immunol. 171:5140-5147.

50. Mendiratta, S.K., et al. 1997. CD1d1 mutant mice are deficient in natural $\mathrm{T}$ cells that promptly produce IL-4. Immunity. 6:469-477.

51. Van Kaer, L., Ashton-Rickardt, P.G., Ploegh, H.L., and Tonegawa, S. 1992. TAP1 mutant mice are deficient in antigen presentation, surface class I molecules, and CD4-8 ${ }^{+}$T cells. Cell. 71:1205-1214.

52. Cui, J., et al. 1997. Requirement for V $\alpha 14$ NKT cells in IL-12-mediated rejection of tumors. Science. 278:1623-1626.

53. Stanic, A.K., et al. 2003. Defective presentation of the CD1d1-restricted natural Va14Ja18 NKT lymphocyte antigen caused by $\beta$-D-glucosylceramide synthase deficiency. Proc. Natl. Acad. Sci. U. S. A. 100:1849-1854. 